\title{
FISCAL DEFICIT AND ECONOMIC GROWTH IN EASTERN EUROPEAN TRANSITION COUNTRIES. IS THERE A LINK?
}

\begin{abstract}
Summary
The countries of Central and Eastern Europe, despite similarities in their routes towards market economy and the EU membership, often differed in their choices regarding fiscal policy and the fiscal instruments to be applied while trying to attain their social and economic goals. At the same time, the social and economic effects of the fiscal measures applied sometimes deviated from the intended ones. Some of the new postcommunist members of the European Union have already joined - and others aspire to join - the Eurozone, whose stability depends on compliance with the adopted fiscal criteria. All those developments give rise to questions about the most efficient fiscal solutions available to the national economies in the process of attaining the assumed economic goals. Another question well worth considering is whether in the perspective of further economic integration the nations of the former Eastern Block are capable of continuously meeting the fiscal criteria of such an integration. The recent developments in Greece have demonstrated that even the "old" EU members may have some problems there, and that such problems affect other members of the European Community. The analysis has demonstrated the risks related to unsound selection of fiscal policy instruments that are run by the countries of Central and Eastern Europe. The core objective of fiscal policy is attaining a high rate of sustainable economic growth. However, the emerging economies are often tempted to achieve the short-term social objectives. The budget deficit may be utilised to achieve such objectives e.g. to maintain a political consensus. Still, a frequent side effect is an increased public debt.
\end{abstract}

Key words: Public Economics, Fiscal Policies, National Budget, Deficit, and Debt.

\section{Introduction}

The fiscal policy, construed as the strategic choices referring both to the sources and methods of public revenue collection and to the directions and rules of public spending in view of reaching the social and economic goals defined by competent public authorities, is of primary importance in the process of creating sustainable economic growth. The efficacy of fiscal policy heavily depends on the selection of adequate fiscal instruments. Such a selection is determined, among other things, by the social and economic characteristics of any given country.

The countries of Central and Eastern Europe, despite similarities in their routes towards market economy and the EU membership, often differed in their choices regarding fiscal policy and the fiscal instruments to be applied while trying to attain

\footnotetext{
${ }^{1}$ Arkadiusz Żabiński, Ph.D. - Faculty of Economics, Management and Tourism in Jelenia Góra, Wrocław University of Economics, e-mail: azabiz@gazeta.pl
} 
their social and economic goals. At the same time, the social and economic effects of the fiscal measures applied sometimes deviated from the intended ones. Some of the new post-communist members of the European Union have already joined - and others aspire to join - the Eurozone, whose stability depends on compliance with the adopted fiscal criteria. All those developments give rise to questions about the most efficient fiscal solutions available to the national economies in the process of attaining the assumed economic goals. Another question well worth considering is whether in the perspective of further economic integration the nations of the former Eastern Block are capable of continuously meeting the fiscal criteria of such an integration. The recent developments in Greece have demonstrated that even the "old" EU members may have some problems there, and that such problems affect other members of the European Community.

The aim of this paper is to analyse of the choice and efficiency of the fiscal instruments applied in the Central and Eastern Europe countries in reaching the primary objective of any fiscal policy, which is to facilitate sustainable economic growth. The analysis also covers selected components of individual fiscal strategies and their capacity to secure unfailing compliance with the fiscal criteria of Eurozone admission. In terms of time, the analysis covers the 2001-2013 period, while in terms of geographical scope - the economies of Bulgaria, the Czech Republic, Estonia, Hungary, Latvia, Lithuania, Poland, Romania, Slovakia and Slovenia. The survey made use of descriptive and statistical methods. The selection of national economies was based on geographical and historical criteria. All the analysed countries underwent the transition to market economy at about the same time and they brought similar historical experiences into the European Union. In all of them the economic transformation entailed similar social tensions that the fiscal policy was expected to ease. Article is an adaptation of the concept of fiscal, appearing in the literature, the fiscal policy pursued by the countries examined.

\section{Fiscal relations in the EU countries}

An indispensable element of any discussion on the efficiency of fiscal policy is setting the objectives which they should foster. Zdzisław Fedorowicz [1998] writes about "specific social and economic objectives", while Danuta Hübner [1992] explicitly defines the objective of fiscal policy as "creation of aggregated demand". Other frequently mentioned fiscal policy objectives are price stabilisation, ensuring full employment, balance of trade, or satisfactory levels of economic growth [Neumark, Fritz, 1997]. For Abba Lerner [Domaszewicz, 1991], the primary objective of fiscal policy was to ensure full employment and prevent inflation through managing the sum total of domestic spending (both public and private).

The fiscal policy objectives are often defined in very broad terms. Article 98 of the Maastricht Treaty states that the EU member states should conduct their economic policies with a view to contributing to the achievement of the objectives of the Community, as defined in Article 2, those including e.g. sustainable and non-inflationary growth, a high level of employment, the raising of the standard of living and the economic and social cohesion. They should also act in accordance with the principle 
of an open market economy with free competition, favouring an efficient allocation of resources, and in compliance with the principles set out in Article 4, i.e. free competition, open market economy, stable prices, sound public finances and monetary conditions and a sustainable balance of payments [Czernielewska-Rutkowska, 2003]. However, such a broad definition of fiscal policy objectives quickly acquires a more specific shape in various financial plans and programmes that reach parliaments as budget-related bills. What is of crucial importance there is preserving the compliance of the objectives of economic policy, fiscal policy and individual economic programmes and regulations.

Implication which affects the fiscal choices of the EU member countries in Central and Eastern Europe is the potential impact of national fiscal policy on the situation of other EU members. The external effects of economic policies are not limited to the monetary union member countries only - they are felt to a greater or lesser extent in any situation of two or more countries linked by economic relations. It should be noted, however, that the EMU is a special case here. Firstly, because the direct macroeconomic effects are stronger due to stronger ties between the monetary union members. Secondly, as Antonio Fatas and Ilian Mihov [2003] point out, there is a specific type of external effects which occur solely in monetary unions and are related to the credibility of common monetary policy and the risk that a country with unsound fiscal policy may require support from other member countries or from the common central bank. A similar point is made by Michael Artis and Bernhard Winkler [1999], who argue that the newly established European Central Bank may lack on the established reputation, credibility and general public support enjoyed by the central banks with a long history of effectively preventing inflation behind them. Potentially, this might increase the risk of the central bank yielding to the pressures from fiscal policies. Thirdly, in a monetary union the politicians may be more inclined to run an unsound fiscal policy since the benefits of such a policy would stay with them, while the costs resulting from rising the interest rates would be spread evenly among all the union members [Beetsma, Uhlig, 1999]. This is related to the diluted disciplining effect of financial markets, as in a monetary union there is no exchange rate risk. Even if (like in the EMU) there are legal barriers to member countries' offering a bail-out to their peer exposed to an insolvency hazard, the listed price of the bonds issued by such a country is unlikely to reflect the insolvency hazard in accordance with the arm's length principle [ECB, 2004].

With regard to the above, members of a monetary union may show an inclination for an unsound fiscal policy just because its cost would be split among the union member countries. On the other hand, in such a situation the member countries are vitally interested in none of their number running such an unsound policy. Those relations provide a motivation to introduce within a monetary union such fiscal rules as would prevent the member countries from incurring an excessive debt.

Quite a few authors [e.g. Wyplosz, 2002; Buiter et al., 1993] also argue that the potential for external effects arising from the fiscal policies run by countries belonging to an economic or monetary union enforces international coordination. However, this concept also has its opponents [e.g. Alesina et al., 2001] who claim that an active coordination is unnecessary as long as the economic policy meets its objectives. Another argument against active coordination may be the results obtained by Beetsma et al. [2001], who 
demonstrated that within a monetary union a fiscal policy coordination is most needed in the situation of a strong asymmetric shock, i.e. precisely when such a coordination is hardest to implement in practice.

To sum up, it can be stated that for the new EU member countries of Central and Eastern Europe their membership in the economic and monetary union may result in a strong dependence of their own fiscal policies on those of other member countries. However, the same can work in the opposite direction - an unsound fiscal policy from one of the new member countries would significantly affect the economic situation of other members. The example of Greece shows how strong an impact of a member's erroneous fiscal policy on the other monetary union members can be.

The source of unsound fiscal policy are the phenomena lying within the scope of political economy and related to a "deficit bias" [Alesina, Perotti, 1994]. The bias results from discretionary actions of the authorities and asymmetry of feedback between the decision-makers and the electorate. The first phenomenon to be taken into account is the so-called "fiscal illusion". This illusion affects the electorates who cannot predict the future burdens to arise from the liberal fiscal policy of the present decision-makers. This phenomenon gets intensified when the financing of the currently liberal fiscal policy is spread across many social groups [Buchanan, Wagner, 1977]. Due to the universal nature of "fiscal illusion", the fiscal policy measures implemented to stabilize the business cycle stop being symmetrical - no budget surplus is generated during an economic upturn. Another significant outcome of the "fiscal illusion" is a political business cycle [Nordhaus, 1975], arising from the instrumental use of fiscal policy in political disputes. As the politicians try to win as many votes as possible, more often than not the fiscal policy run just before the elections has an expansionary bias. The budget spending gets increased or the tax burdens cut. This stimulates the economy, but at the same time accumulates the budget deficit, which at the end of the government's term of office is higher than at the beginning.

The bias towards budget deficit and consequently towards public debt is also related to the "common resource pool" [von Hagen, 2005]. Individual stakeholder groups involved in budget-related decision-making try to get as many resources transferred to them as possible, at the expense of other stakeholders. This tendency is generally believed to be stronger in multi-party coalition governments [Alesina, Tabellini, 1990] or where the political landscape is polarised and the ruling coalitions change frequently [Buti, van den Noord, 2003]. Any tightening of fiscal policy requires taking a decision on reducing the flow of budget funds towards some social groups. An announcement of such intentions may lead to contention between individual groups to keep their former privileges, i.e. the so-called "war of attrition". As a result, the actions for tightening the fiscal policy usually get postponed.

It is worth noticing here that the governments who are politically weaker tend to postpone the adjustment measures and to accumulate debt [Alesina and Perotti, 1994]. Other political factors which cause persistent budget deficit and public debt accumulation include reiterating the former declarations on tightening the fiscal policy on the grounds of "unforeseen developments" [Kydland, Prescott, 1977]. Another important factor is the pressure for increasing the public administration spending, especially when the 
efficiency, rate and methods of utilizing the resources allocated to the operation of governmental agencies are not sufficiently monitored.

The factors leading to unsound fiscal policy also enhance its pro-cyclical impact on economy. As already mentioned above, during an economic upturn the "fiscal illusion" gives rise to a bias towards either increased spending or tax cuts. A good budget position is considered by the electorate a favourable time for the government to implement their pre-election promises, e.g. tax burden cuts.

An interest in using the surplus budget resources during an upturn leads to the socalled "voracity effect" [Tornell, Lane, 1999], resulting in a rate of public spending that outpaces revenue inflows.

In some situations, a pro-cyclical fiscal policy bias may also be related to the application of numerical fiscal rules [Buiter, Corsetti, Roubini, 1993]. Such a situation may occur where the value of the indicator on which the numerical rule is hooked is not business cycle-adjusted, or where no downturn-related exemptions from the rule have been provided for. If an economic decline brings a danger of breaking the numerical limits, the government may feel forced to apply a pro-cyclical tightening of fiscal policy, thus reducing the symmetry of automatic stabilizers.

It must be emphasized here that the specifics of socio-economic situation in the new EU member countries undergoing transformation puts them at the risk of committing more fiscal errors and omissions than the stable market economies. However, if those countries intend to actively participate in the European integration, they will have to rapidly adjust their fiscal policies to those of the Eurozone. If they do not, their fiscal policies are likely to have a negative impact on the sustainability of economic growth which is the primary objective of both the new and the old EU member countries.

\section{Fiscal policy assessment criteria}

In order to assess the fiscal policy of any country, it is necessary to select proper criteria first. The definition of acceptable levels of budget deficit and public debt was a subject of European institutions' surveys and analyses for many years. In an attempt to protect the common currency from the negative impacts of unsound fiscal policies, some threshold values generally recognised as safe for long-term economic growth were adopted as convergence criteria.

In the Maastricht Treaty [1992], whose provisions were intended to enforce fiscal discipline within the prospective economic and monetary union so as to ensure a "safety margin" in case of a shock or recession, there was a provision requiring the national debt not to exceed $60 \%$ GDP while the public sector deficit should not reach 3\% GDP. Moreover, neither the member countries not the European Communities are responsible for the debt of other members. Exceeding the threshold values adopted as fiscal criteria triggers the excessive deficit procedure. Under the procedure, the government must implement measures to reduce the deficit and any country failing to do so may expect sanctions imposed, e.g. an obligation to make a non-interest bearing deposit. Assessment of compliance with the Maastricht criteria is done on the ex post basis. 
In 1997 those regulations were complemented with the Stability and Growth Pact. One of the core objectives of the Pact was further strengthening and sustaining of the necessary fiscal discipline upon creation of the European Monetary Union. While the fiscal criteria of the Maastricht Treaty were being introduced, there were fears that the fixed maximum allowable deficit level (3\% of GDP) may produce a pro-cyclical effect through enforcing the tightening of fiscal policy during downturn periods and thus may limit the stabilizing capacity of fiscal policies. Therefore, the fiscal policy patterns proposed in the Stability and Growth Pact were intended to ensure sustained compliance with the Maastricht criteria through a commitment to achieve mid-term budget positions close to balance or in surplus. Thanks to that, a free operation of automatic stabilisers should not present a risk of exceeding the reference value of public sector deficit.

In 2002 it was decided that countries not meeting the Maastricht criteria should take remedial measures to achieve an annual reduction of their deficit by at least $0.5 \%$ of GDP. The post-2001 economic downturn demonstrated that the EU fiscal rules then in force did not fully rise to expectations. The downgrading of budget positions in member countries revealed the defects of the existing sanction mechanism. There were numerous objections to the decision waiving additional measures under the excessive deficit procedure against France and Germany despite a notice from the European Commission stating that the countries do not fulfil their commitments for deficit reduction. The decision was finally rescinded by the European Court of Justice in Luxembourg. However, the whole situation was considered a glaring example of the sanction mechanism dependence on political decisions.

This led to commencing the work on changes to the Stability and Growth Pact, which were finally adopted in 2005. It was decided that the values of fiscal policy indicators would be set separately for every country, with regard to their different economic and fiscal situation and the varied scale of potential threat to public finance stability. The lower limit for medium-term budgetary objectives (MTO) for the EMU and ERM II countries was defined as a structural deficit amounting to 1\% of GDP. The structural debt and deficit levels were to be set so as to prevent the nominal deficit exceeding the reference value as well as to ensure that the public finances are quickly brought to a position securing their long-term stability. The first condition is met by making the fiscal indicators dependent on the budget sensitivity to business cycle. Meanwhile, the long-term stability assessment should take account of all the overt and hidden commitments of public finances, including in particular the future liabilities towards the ageing society. Since meeting this requirement is a highly complicated task, for the initial stage a simplified method of ensuring long-term stability in setting MTOs was adopted. The method consisted in defining an MTO in relation to the current level of public debt and to the potential GDP growth rate.

During the discussion on applying the fiscal indicators for assessment of the economic condition of individual countries, an increased attention was paid to the public finance stability and to the criterion of public debt-to-GDP ratio. This was because research [Pisani-Ferry, 2002] had demonstrated that a stability assessment should be performed on the basis of just that criterion rather than the reference value which relied on the public finance balance. Using the deficit size as a primary measure may obstruct the necessary 
structural reforms and constrain public investment [Balassone, Franco, 2000]. This is because this type of spending, important from the point of view of economic development, is easier to reduce than e.g. social transfers. There was also a change made to the provision defining the situation where a deficit exceeding the reference value is still not considered excessive.

It took several years for the European institutions to specify the fiscal policy criteria for sustainable economic development. During that time, the criteria were subject to numerous analyses, debates, critique and modifications. Even though the adopted criteria were generally accepted, there were also some critical opinions expressed. It was pointed out that public debt levels in the new EU member countries of Central and Eastern Europe were much lower than those of the "old" EU countries, while their GDP dynamics was much higher [Buiter, Grafe, 2002]. At the same time, it was noted that their fiscal policies will face heavy challenges, related e.g. to the underdeveloped public infrastructure. Those arguments imply that it would be reasonable for the new EU members to be temporarily allowed deficits exceeding the reference value of $3 \%$ of GDP.

To sum up, it can be stated that all the aforementioned criteria for assessing the condition of a national economy are meant to serve the primary objective of fiscal policy, which is securing a rapid and sustainable economic growth. It is just the level of meeting this objective that will be the ultimate criterion in assessing the efficiency of fiscal policies in the countries in question.

\section{Fiscal instruments in creating economic growth in the countries of Central and Eastern Europe}

The analysed economies demonstrated diverse rates of economic growth. The average geometric rate of GDP increase during the 2001-2013 period was 2.29\%. It should be stressed here that during that time the annual average economic growth in the ten countries in question was much faster than the EU average of a mere $0.53 \%$.

Both the highest and the lowest annual growth rates were recorded in Latvia $-+11 \%$ in 2006 and $-17.7 \%$ in 2008 . However, the lowest overall average growth rate for the period was $1.6 \%$, recorded by Hungary. Conversely, the highest overall harmonic average growth rate for the period was recorded by Lithuania and amounted to $4.36 \%$. Slovakia was not much worse with the average growth rate of $4.13 \%$. The average rates of annual economic growth recorded by other countries amounted respectively to: for Latvia $3.97 \%$, Estonia - 3.88\%, Romania - 3.68\%, Poland - 3.61\%, Bulgaria - 3.38\%, Czech Republic $-2.54 \%$ and Slovenia $-1.82 \%$. The above data justify the statement that within the analysed group there were huge differences in the rate of economic growth. 
TABLE 1.

Growth rate of GDP volume - percentage change on previous year

\begin{tabular}{|l|c|c|c|c|c|c|c|c|c|c|c|c|c|}
\hline & $\mathbf{2 0 0 1}$ & $\mathbf{2 0 0 2}$ & $\mathbf{2 0 0 3}$ & $\mathbf{2 0 0 4}$ & $\mathbf{2 0 0 5}$ & $\mathbf{2 0 0 6}$ & $\mathbf{2 0 0 7}$ & $\mathbf{2 0 0 8}$ & $\mathbf{2 0 0 9}$ & $\mathbf{2 0 1 0}$ & $\mathbf{2 0 1 1}$ & $\mathbf{2 0 1 2}$ & $\mathbf{2 0 1 3}$ \\
\hline Bulgaria & 4.1 & 4.7 & 5.5 & 6.7 & 6.4 & 6.5 & 6.4 & 6.2 & -5.5 & 0.4 & 1.8 & 0.6 & 0.9 \\
Czech Re. & 2.5 & 2.1 & 3.8 & 4.7 & 6.8 & 7.0 & 5.7 & 3.1 & -4.5 & 2.5 & 1.8 & -1.0 & -0.9 \\
Estonia & 7.5 & 6.6 & 7.8 & 6.3 & 8.9 & 10.1 & 7.5 & -4.2 & -14.1 & 2.6 & 9.6 & 3.9 & 0.8 \\
Latvia & 8.0 & 7.1 & 7.7 & 8.8 & 10.1 & 11.0 & 10.0 & -2.8 & -17.7 & -1.3 & 5.3 & 5.2 & 4.1 \\
Lithuania & 6.7 & 6.8 & 10.3 & 7.4 & 7.8 & 7.8 & 9.8 & 2.9 & -14.8 & 1.6 & 6.0 & 3.7 & 3.3 \\
Hungary & 4.1 & 4.5 & 3.9 & 4.8 & 4.0 & 3.9 & 0.1 & 0.9 & -6.8 & 1.1 & 1.6 & -1.7 & 1.1 \\
Poland & 1.2 & 1.4 & 3.9 & 5.3 & 3.6 & 6.2 & 6.8 & 5.1 & 1.6 & 3.9 & 4.5 & 2.0 & 1.6 \\
Romania & 5.7 & 5.1 & 5.2 & 8.5 & 4.2 & 7.9 & 6.3 & 7.3 & -6.6 & -1.1 & 2.3 & 0.6 & 3.5 \\
Slovenia & 2.8 & 3.8 & 2.9 & 4.4 & 4.0 & 5.8 & 7.0 & 3.4 & -7.9 & 1.3 & 0.7 & -2.5 & -1.1 \\
Slovakia & 3.5 & 4.6 & 4.8 & 5.1 & 6.7 & 8.3 & 10.5 & 5.8 & -4.9 & 4.4 & 3.0 & 1.8 & 0.9 \\
\hline
\end{tabular}

Source: [Eurostat, http://epp.eurostat.ec.europa.eu/portal/page/portal/eurostat/home/, date of access: 6.06.2014].

For the ten economies analysed, the average rate of public spending during the 2001-2013 period was $40.97 \%$ of GDP. This is a lower ratio than the EU-27 average, which reached $46.59 \%$ of GDP.

TABLE 2.

Total general government expenditure - General government ( $\%$ of GDP)

\begin{tabular}{|l|l|l|l|l|l|l|l|l|l|l|l|l|l|}
\hline & $\mathbf{2 0 0 1}$ & $\mathbf{2 0 0 2}$ & $\mathbf{2 0 0 3}$ & $\mathbf{2 0 0 4}$ & $\mathbf{2 0 0 5}$ & $\mathbf{2 0 0 6}$ & $\mathbf{2 0 0 7}$ & $\mathbf{2 0 0 8}$ & $\mathbf{2 0 0 9}$ & $\mathbf{2 0 1 0}$ & $\mathbf{2 0 1 1}$ & $\mathbf{2 0 1 2}$ & $\mathbf{2 0 1 3}$ \\
\hline Bulgaria & 40.3 & 39.6 & 39.1 & 38.6 & 37.3 & 34.4 & 39.2 & 38.4 & 41.4 & 37.4 & 35.6 & 35.8 & 38.7 \\
Czech Rep. & 44.4 & 50.0 & 43.3 & 43.0 & 42.0 & 41.0 & 41.1 & 41.2 & 44.7 & 43.7 & 43.2 & 44.5 & 42.3 \\
Estonia & 34.8 & 35.8 & 34.8 & 34.0 & 33.6 & 33.6 & 34.0 & 39.7 & 44.7 & 40.5 & 37.6 & 39.5 & 38.3 \\
Latvia & 34.6 & 36.0 & 34.9 & 35.9 & 35.8 & 38.3 & 36.0 & 39.1 & 43.6 & 43.4 & 38.4 & 36.5 & 36.1 \\
Lithuania & 36.8 & 35.4 & 33.8 & 34.0 & 34.0 & 34.2 & 35.3 & 37.9 & 44.9 & 42.3 & 38.7 & 36.1 & 34.5 \\
Hungary & 47.3 & 51.5 & 49.7 & 49.1 & 50.1 & 52.2 & 50.7 & 49.2 & 51.4 & 50.0 & 50.0 & 48.7 & 50.0 \\
Poland & 43.8 & 44.2 & 44.7 & 42.6 & 43.4 & 43.9 & 42.2 & 43.2 & 44.6 & 45.4 & 43.4 & 42.2 & 41.9 \\
Romania & 36.0 & 35.0 & 33.5 & 33.6 & 33.5 & 35.3 & 38.2 & 39.3 & 41.1 & 40.1 & 39.4 & 36.7 & 35.0 \\
Slovenia & 47.6 & 46.3 & 46.2 & 45.6 & 45.2 & 44.5 & 42.4 & 44.2 & 48.7 & 49.5 & 49.9 & 48.4 & 59.4 \\
Slovakia & 44.5 & 45.1 & 40.1 & 37.6 & 38.0 & 36.9 & 34.4 & 34.8 & 41.6 & 39.8 & 38.9 & 38.2 & 38.7 \\
\hline
\end{tabular}

Source: [Eurostat, http://epp.eurostat.ec.europa.eu/portal/page/portal/eurostat/home/, date of access: 6.06.2014].

Among the economies analysed, the rate of public spending was kept lowest by Lithuania - at $34.64 \%$ of GDP. The highest spending-to-GDP ratio occurred in Hungary, where it amounted to $49.99 \%$ on average. During the same period, low values of public spending-to-GDP ratio were also maintained by: Romania - 35.15\%, Estonia - 35.21\%, Latvia $-36.16 \%$, Slovakia $-38.91 \%$ and Bulgaria - 39.4\%. Even the economies with highest spending rates in the group, namely Poland with $43.5 \%$ of GDP, Czech Republic with $44.65 \%$ of GDP and Slovenia with $45.3 \%$ of GDP, did not reach the EU average. The post-communist economies which accessed the European Union generally keep their public expenditures low. The countries with the lowest spending-to-GDP ratios at the 
same time present the highest rate of economic growth. On the other side, the Hungarian economy with the highest spending-to-GDP ratio in the group at the same time presents the lowest rate of economic growth. The same refers to Poland and the Czech Republic.

TABLE 3.

Net borrowing/lending of consolidated general government sector as a percentage of GDP

\begin{tabular}{|l|r|r|r|r|r|r|r|r|r|r|r|r|r|}
\hline & $\mathbf{2 0 0 1}$ & $\mathbf{2 0 0 2}$ & $\mathbf{2 0 0 3}$ & $\mathbf{2 0 0 4}$ & $\mathbf{2 0 0 5}$ & $\mathbf{2 0 0 6}$ & $\mathbf{2 0 0 7}$ & $\mathbf{2 0 0 8}$ & $\mathbf{2 0 0 9}$ & $\mathbf{2 0 1 0}$ & $\mathbf{2 0 1 1}$ & $\mathbf{2 0 1 2}$ & $\mathbf{2 0 1 3}$ \\
\hline Bulgaria & 0.6 & -1.2 & -0.4 & 1.9 & 1.0 & 1.9 & 1.2 & 1.7 & -4.3 & -3.1 & -2.0 & -0.8 & -1.5 \\
Czech Rep. & -5.6 & -6.5 & -6.7 & -2.8 & -3.2 & -2.4 & -0.7 & -2.2 & -5.8 & -4.7 & -3.2 & -4.2 & -1.5 \\
Estonia & -0.1 & 0.3 & 1.7 & 1.6 & 1.6 & 2.5 & 2.4 & -3.0 & -2.0 & 0.2 & 1.1 & -0.2 & -0.2 \\
Latvia & -2.1 & -2.3 & -1.6 & -1.0 & -0.4 & -0.5 & -0.7 & -4.4 & -9.2 & -8.2 & -3.5 & -1.3 & -1.0 \\
Lithuania & -3.6 & -1.9 & -1.3 & -1.5 & -0.5 & -0.4 & -1.0 & -3.3 & -9.4 & -7.2 & -5.5 & -3.2 & -2.2 \\
Hungary & -4.0 & -9.0 & -7.2 & -6.4 & -7.9 & -9.3 & -5.1 & -3.7 & -4.6 & -4.3 & 4.3 & -2.1 & -2.2 \\
Poland & -5.1 & -5.0 & -6.3 & -5.7 & -4.1 & -3.6 & -1.9 & -3.7 & -7.5 & -7.8 & -5.1 & -3.9 & -4.3 \\
Romania & -3.5 & -2.0 & -1.5 & -1.2 & -1.2 & -2.2 & -2.9 & -5.7 & -9.0 & -6.8 & -5.5 & -3.0 & -2.3 \\
Slovenia & -4.0 & -2.5 & -2.7 & -2.2 & -1.4 & -1.3 & 0.0 & -1.9 & -6.3 & -5.9 & -6.4 & -4.0 & -14.7 \\
Slovakia & -6.5 & -8.2 & -2.8 & -2.4 & -2.8 & -3.5 & -1.8 & -2.1 & -8.0 & -7.5 & -4.8 & -4.5 & -2.8 \\
\hline
\end{tabular}

Source: [Eurostat, http://epp.eurostat.ec.europa.eu/portal/page/portal/eurostat/home/, date access: 6.06. 2014].

During the 2001-2013 period, for the countries in question the average rate of budget deficit as compared to GDP was 3.14\%. This value exceeds the EU-27 average deficit of $2.7 \%$. This relationship seems to confirm the hypothesis of the new EU members having deficits naturally exceeding the European average. On the other hand, an analysis of individual years within the period shows that some countries at times exceeded this reference value The highest annual budget surplus $(2.5 \%)$ was reported by Estonia in 2006. With reference to the average value of budget deficit-to-GDP ratio throughout the period analysed, again the country having the highest average deficit was Hungary with its ratio of $4.73 \%$. Also in Poland the average deficit was high, at $4.68 \%$. The average rates of budget deficits reported by other countries amounted respectively to: for Slovakia $-4.4 \%$, Slovenia $-4.1 \%$, Czech Republic $-3.8 \%$, Romania $-3.6 \%$, Lithuania $-3.1 \%$, Latvia $-2.7 \%$ and Bulgaria - $0,38 \%$. The only country who managed to average a positive budget balance throughout the period analysed was Estonia $(0.45 \%)$. The rise Pearsons correlative relationship between GDP and the budget deficit is strongest in Latvia $(0,88)$, Lithuania $(0,84)$ and Estonia $(0,82)$. Strong relationship also occurs in the Bulgaria $(0,79)$, Romania $(0,74)$, Slovenia $(0,6)$ and Slovakia $(0,55)$. Only in Poland and Hungary the correlation is weak. The above values allow the conclusion of an adverse impact of a high budget deficit on economic growth. The countries who had low budget deficit or even a surplus registered a higher rate of economic growth than those with high budget deficit levels. This is contrary to the claim that the new EU member countries use their high budget deficit levels to improve their capacities for EU funding absorption and increase the rates of economic growth. It seems that the high budget deficit levels are rather symptomatic of delays in economy transformations 
and public finance reforms. This hypothesis finds its confirmation in the data referring to the public debt-to-GDP ratio.

TABLE 4.

General government consolidated gross debt as a percentage of GDP

\begin{tabular}{|l|r|r|r|r|r|r|r|r|r|r|r|r|r|}
\hline & $\mathbf{2 0 0 1}$ & $\mathbf{2 0 0 2}$ & $\mathbf{2 0 0 3}$ & $\mathbf{2 0 0 4}$ & $\mathbf{2 0 0 5}$ & $\mathbf{2 0 0 6}$ & $\mathbf{2 0 0 7}$ & $\mathbf{2 0 0 8}$ & $\mathbf{2 0 0 9}$ & $\mathbf{2 0 1 0}$ & $\mathbf{2 0 1 1}$ & $\mathbf{2 0 1 2}$ & $\mathbf{2 0 1 3}$ \\
\hline Bulgaria & 67.3 & 53.6 & 45.9 & 37.0 & 29.2 & 22.7 & 17.2 & 13.7 & 14.6 & 16.2 & 16.3 & 18.4 & 18.9 \\
Czech Rep. & 24.9 & 28.2 & 29.8 & 30.1 & 29.7 & 29.4 & 27.9 & 28.7 & 34.6 & 38.4 & 41.4 & 46.2 & 46.0 \\
Estonia & 4.8 & 5.7 & 5.6 & 5.0 & 4.6 & 4.5 & 3.7 & 4.5 & 7.1 & 6.7 & 6.1 & 9.8 & 10.0 \\
Latvia & 14.0 & 13.5 & 14.6 & 14.9 & 12.4 & 10.7 & 9.0 & 19.8 & 36.9 & 44.5 & 42.0 & 40.8 & 38.1 \\
Lithuania & 23.1 & 22.3 & 21.1 & 19.4 & 18.4 & 18.0 & 16.9 & 15.5 & 29.3 & 37.8 & 38.3 & 40.5 & 39.4 \\
Hungary & 52.0 & 55.6 & 58.4 & 59.1 & 61.8 & 65.6 & 65.9 & 73.0 & 79.8 & 82.2 & 82.1 & 79.8 & 79.2 \\
Poland & 37.6 & 42.2 & 47.1 & 45.7 & 47.1 & 47.7 & 45.0 & 47.1 & 50.9 & 54.9 & 56.2 & 55.6 & 57.0 \\
Romania & 25.7 & 24.9 & 21.5 & 18.7 & 15.8 & 12.4 & 12.6 & 13.6 & 23.6 & 30.5 & 34.7 & 38.0 & 38.4 \\
Slovenia & 26.8 & 28.0 & 27.5 & 27.2 & 27.0 & 26.7 & 23.3 & 22.0 & 35.2 & 38.7 & 47.1 & 54.4 & 71.7 \\
Slovakia & 48.9 & 43.4 & 42.4 & 41.5 & 34.2 & 30.5 & 29.3 & 27.9 & 35.6 & 41.0 & 43.6 & 52.7 & 55.4 \\
\hline
\end{tabular}

Source: [Eurostat, http://epp.eurostat.ec.europa.eu/portal/page/portal/eurostat/home/, date access: 6.06.2014].

Throughout the period analysed, only two of the countries in question ever exceeded the $60 \%$ cap on the proportion of public debt to GDP: Bulgaria, Slovenia (for one year) and Hungary (for nine consecutive years). The situation of Hungary is the more dangerous that during the 2001-2013 period its public debt grew steadily from 52\% to 79.2\%. And the debt kept growing despite the fact that since 2006 Hungary has been gradually reducing its budget deficit. During the 2001-2013 period, the average value of debtto-GDP ratio for the economies in question was $33.6 \%$, which is definitely lower than the EU-27 average of $61.2 \%$ for the same period. However, the differences in public debt levels between individual countries were large indeed. Half of the countries: Bulgaria, Estonia, Latvia, Lithuania and Romania surveyed had a average public debt of less than $30,1 \%$ GDP. At the same time, those countries obtaining the highest economic growth rates.

\section{Conclusions}

Bulgaria, the Czech Republic, Estonia, Hungary, Latvia, Lithuania, Poland, Romania, Slovakia and Slovenia are all countries in Central and Eastern Europe who had similar experiences on their way to economic and political transformation. All of them had to reform their economies as a consequence of the economic and political transformation. Their transition from the centralised to free-market economy entailed various social tensions and economic costs. However, they did not choose the same fiscal solutions to attain their economic goals. Each of the countries decided to apply its specific set of fiscal instruments to arrive at economic growth.

The analysis of fiscal policies run by the Central and Eastern Europe countries in question demonstrates a significant divergence in their approach to individual aggregates, 
but also many regularities which all of them share. It can be observed that all those countries are subject to a competitive pressure with respect to the fiscal burdens imposed within their economies. While competing for investment capital, the Central and Eastern Europe countries reduce the fiscal burdens and that results - for all of them - in the public revenue-to-GDP ratios below the European average. Therefore it may be assumed that in this way those economies have been trying to acquire the capital necessary to finance their long-term economic growth. However, while the decisions to put their public sector revenues low are relatively easy, the decision to curb public expenditure is not necessarily so. In this context, the position of Hungary seems particularly dangerous as its public spending level has exceeded the European average and is coming close to that of Scandinavian countries.

A very different approach to their budgets was adopted by Lithuania, Latvia and Estonia. Those countries adjusted their public spending to low public revenues and run a small-budget policy. In order to maintain the adopted fiscal standards, those countries had to enforce unpopular reforms which allowed to keep spending low. Obviously, it could be argued that The Hungarian policy might be devised for a long-term success. The high public spending levels might favour the absorption of EU funds. However, this concept should be bringing high rate of economic growth, while the situation in Hungary is just the opposite.

The objective of the adopted approach to fiscal policy is attaining a high rate of sustainable economic growth. The decisions related to public revenues and spending, budget deficit and public debt are to foster this primary objective notwithstanding the criteria set forth in the European treaties. However, compliance with the fiscal criteria allows reaching a rate of economic growth that is definitely higher than the one obtained while exceeding the deficit and/or debt reference values. The example of the EU member countries of Central and Eastern Europe clearly demonstrates the relationship between the high fiscal standards and the rate of economic growth. The public revenue levels, budgeted below the European average due to competing for investment capital, have enforced other measures related to public spending, budget balance and - consequently - public debt. Running a prudent fiscal policy required the countries of Central and Eastern Europe to follow the socially controversial path of system transformation. However, this brought about a high rate of economic growth. Therefore, it may be concluded that maintaining the low levels of public revenues and spending as well as budget deficit and public debt ensure not only meeting the convergence criteria but also a higher rate of economic growth than that attained by the non-compliant countries.

The analysis has demonstrated the risks related to unsound selection of fiscal policy instruments that are run by the countries of Central and Eastern Europe. The core objective of fiscal policy is attaining a high rate of sustainable economic growth. However, the emerging economies are often tempted to achieve the short-term social objectives. The budget deficit may be utilised to achieve such objectives e.g. to maintain a political consensus. Still, a frequent side effect is an increased public debt. The Hungarian economy makes an example of the adverse impact of unsound selection of fiscal instruments to reach short-term objectives. The sluggish GDP is just an outcome of such policies. Consequently, the next objective of the Hungarian government must be restoring 
the balance of public finances. It seems that the Hungarian government suffers from a deficit - first voluntary and then imposed - of instruments to create a long-term, sustainable economic growth. It seems that the fiscal solutions applied by the Baltic states or Romania are best-suited to the specifics of the emerging economies of Central and Eastern Europe. Maintaining the discipline of public finances, low budget deficit and consequently low public debt translate into high rates of economic growth. In this case, the primary objective of fiscal policy prevails over the short-term goals. Moreover, in an economy maintaining the discipline of public finances, the fiscal instruments are easier to apply in a situation of such a global economic downturn as the one we saw in the second half of 2008. An analysis of the processes arising from the fiscal policies adopted by Hungary or other countries discussed here seems to be an exercise recommendable for Poland, which still runs the risk of applying the fiscal instruments to short-term goals at the expense of long-term economic growth.

\section{Bibliography}

Alesina A., Blanchard O., Gali J., Giavazzi F., Uhlig H. 2001 Defining a Macroeconomic Framework for the Euro Area, Monitoring the European Central Bank 3, CEPR.

Alesina A., Perotti R. 1994 Political Economy of Budget Deficits, Working Paper, No. 4637, NBER.

Alesina A., Tabellini G. 1990 A Positive Theory of Budget Deficits and Government Debt, "Review of Economic Studies", Vol. 57, No. 3,

Artis M., Winkler B. 1999 The Stability Pact: Trading Off Flexibility for Credibility? [in:] Fiscal Aspects of European Monetary Integration, Hughes Hallett A., Hutchison M.M., Hougaard Jensen S.E. (eds.), Cambridge University Press.

Beetsma R., Debrun X., Klaassen F. 2001 Is Fiscal Policy Coordination in EMU Desirable?, IMF Working Paper, WP/01/178, IMF.

Beetsma R., Uhlig H. 1999 An Analysis of the Stability and Growth Pact, "The Economic Journal", Vol. 109, No. 458, pp. 546-571.

Buchanan J.M., Wagner R.E. 1977 Democracy in Deficit: the Political Legacy of Lord Keynes, Academic Press Inc., New York.

Buiter W., Corsetti G., Roubini N. 1993 Excessive Deficits: Sense and Nonsense in the Treaty of Maastricht, [in:] The Political Economy of Monetary Union, De Grauwe (ed.), Edward Elgar Publishing Ltd, Cheltenham.

Buti M., van den Noord P. 2003 Discretionary Fiscal Policy and Elections: The Experience of the Early Years of EMU, "OECD Economic Department Working Paper”, No. 351, OECD.

European Central Bank 2004 EMU and the Conduct of Fiscal Policies, "ECB Monthly Bulletin", January.

European Central Bank 2004b Convergence Report 2004.

European Commission 2007 Public Finances in EMU 2007, "European Economy", No. 3/2007, Directorate-General for Economic and Financial Affairs. 
Eurostat, http://epp.eurostat.ec.europa.eu/portal/page/portal/government_finan ce_statistics/data/main_table, date of access

Fatas A., Mihov I. 2003 On Constraining Fiscal Policy Discretion in EMU, "Oxford Review of Economic Policy", No 19

Fedorowicz Z. 1998 Polityka fiskalna, Wydawnictwo Wyższej Szkoły Bankowej, Poznań.

Hagen J. von 2005 Political Economy of Fiscal Institutions, GESY Discussion Paper No.149

Hübner D. 1992 Makroekonomiczna polityka stabilizacyjna, Instytut Rozwoju i Studiów Strategicznych, Warszawa.

Kydland F., Prescott E. 1977 Rules Rather Than Discretion: The Inconsistency of Optimal Plans, "Journal of Political Economy", Vol. 85, No. 3.

Neumark F. 1997 Die komparative Bedeutung von Geld-und Fiskalpolitike für die Vervirklichung wirtschaftlicher Stabilität, Berlin.

Nordhaus W. 1975 The Political Business Cycle, "Review of Economic Studies", vol. 42, No. 2

Piotrowska M. 2007, http://mikro.univ.szczecin.pl/bp/pdf/41/10.pdf 16.02.2013.

Tornell A., Lane P.R. 1999 The Voracity Effect, "American Economic Review", Vol. 89, No. 1 ,

Wyplosz Ch. 2002 Fiscal Policy: Rules or Institutions?, The Group of Economic Analysis of the European Commission. 